\title{
Working
}

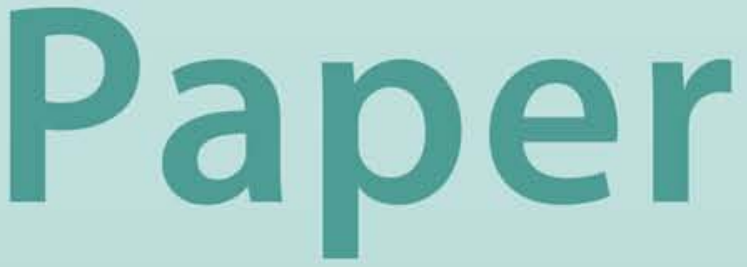




\title{
Bank Reform and Bank Efficiency in Pakistan
}

\author{
Daniel C. Hardy and \\ Emilia Bonaccorsi di Patti
}




\title{
IMF Working Paper
}

Middle Eastern Department

\section{Bank Reform and Bank Efficiency in Pakistan}

\author{
Prepared by Daniel C. Hardy and Emilia Bonaccorsi di Patti ${ }^{1}$ \\ Authorized for distribution by Antônio Furtado
}

September 2001

\begin{abstract}
The views expressed in this Working Paper are those of the author(s) and do not necessarily represent those of the IMF or IMF policy. Working Papers describe research in progress by the author(s) and are published to elicit comments and to further debate.
\end{abstract}

Pakistan undertook major financial sector reforms starting in the late 1980s. The effects of these reforms on the profitability and cost and revenue efficiency of the banking sector are evaluated. The revenue performance of all banks, and especially the privatized banks, improved significantly, although costs also rose and relative performance across banks did not converge.

JEL Classification Numbers:G21, G28, O16, O53

Keywords: Banking, efficiency, deregulation, Pakistan

Author’s E-Mail Address: dhardy@imf.org

${ }^{1}$ Middle Eastern Department, International Monetary Fund, and Banca d'Italia, respectively. The views expressed are those of the authors and not of the IMF or the Banca d'Italia. 


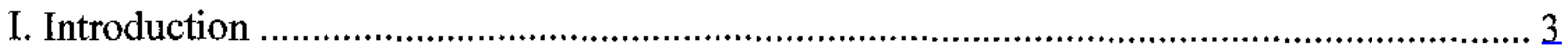

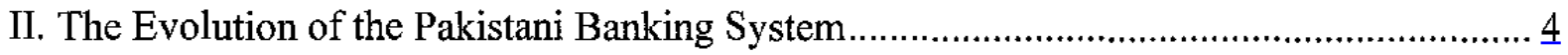

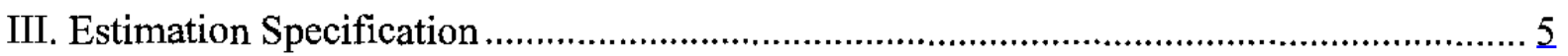

A. Measurement of Changes in Bank Efficiency............................................................ $\frac{5}{8}$

B. Data Sample and Definitions of Variables................................................................ 8

C. Model Specification and Estimation ……………................................................. 17

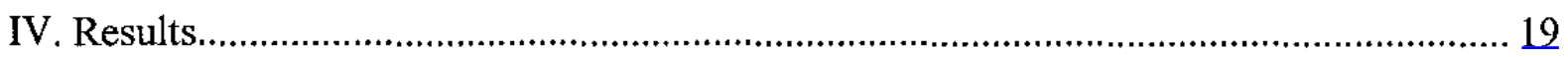

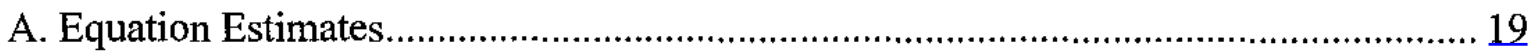

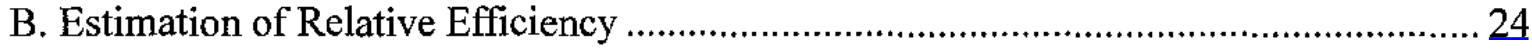

C. Effect of Structural Factors and Market Conditions ................................................... 27

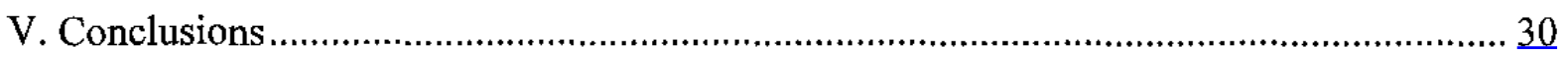

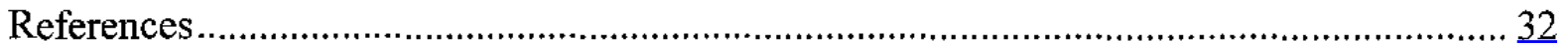

Tables

Table 1. Variable Definitions and Summary Statistics ................................................... 10

Table 2. Estimated Coefficients of Efficiency Frontiers ................................................ 20

Table 3. Estimated Average Profitability, Cost, and Revenue X-efficiency .......................... 25

Table 4. Tests of Significance of Sectoral Dummy Variables............................................ 28

Table 5. Decomposition of Changes in Profitability, Costs, and Revenue............................. 22

Figures

Figure 1. Average Unit Prices and Costs …………..................................................... 13

Figure 2. Revenue to Total Asset Ratios ................................................................. 15

Figure 3. Costs to Total Asset Ratios....................................................................... 15

Figure 4. Capital and Reserves to Total Asset Ratios..................................................... 16

Figure 5. "Due Banks" to Deposits Ratio …………........................................................ 16 


\section{INTRODUCTION}

A large number of industrialized, developing and transition countries have undertaken extensive reforms of their banking systems over the past two decades (see Swary and Topf (1992), Zahid (1995), and Fanelli and Medhora (1998) for surveys). These reforms have included such measures as the liberalization of interest rates, the removal of quantatative controls on lending, the lifting barriers to competition, the privatization of public financial institutions, and the introduction of market-based securities. The principal aims of the reforms has generally been to raise both the level of investment and the efficiency of its allocation, and in addition to enhance the provision of financial services to all sectors of the economy. Pakistan is an important example of a country that, motivated by such considerations, undertook far-reaching financial sector reforms. The effects of the these reforms, which started in the late $1980 \mathrm{~s}$, is the subject of this paper.

The importance of a country's financial sector in itself and its influence on other sectors demands that the reforms that are underetaken and their success be evaluated thoroughly. However, relatively limited international evidence is available on the effects of financial sector reform, especially in developing countries. Due to the time needed to put structural reforms in place and for them to take effect, in many countries convincing evidence regarding this issue is only now accumulating.

Two main approaches exist to evaluate the effects of financial market reforms. The first concentrates on macroeconomic variables that are closely related to the ultimate objectives of reform, - - such as savings and investment rates, real growth, and interest rates, - -and attcmpts to discern changes in their behavior induced by the financial sector reforms. ${ }^{2}$ The main drawback of this approach lies in the difficulty in isolating the effects of financial market reforms from those of other institutional or macroeconomic developments. The difficulty is made more acute by the small number of observations typically available for any one country, and the heterogeneity of experiences across countries.

An alternative approach is based on an analysis of the financial sector itself, and in particular on an assessment of changes in the structure and performance of the sector following reform. To this end, one can attempt to estimate the effects on such variables as the cost efficiency, revenue efficiency, and profitability of the financial institutions operating in one country, which are subject to the same regulatory regime shifts and other disturbances. This approach, which is adopted here, has been followed by Grabowski, Rangan, and Rezvanian (1994), Berger and Mester (1997) and Humphrey and Pully (1997), for example, in looking at the U.S. experience with bank deregulation, and by Lozano-Vivas (1998) for Spanish banks.

${ }^{2}$ Examples include Gelb (1989), Johnston and Pazarbaşioglu (1995), Demetriades and Luintel (1996), Jbili, Enders, and Treichel (1997), Bandiera, Caprio, Honohan, and Schiantarelli (2000), and, specifically regarding Pakistan, Khan and Aftab (1994) and Khan and Hasan (1998). 
Econometric studies of the effects of reform on the financial sector of developing countries are rare, with Gilbert and Wilson (1998) and Leightner and Lovell (1998) being examples known at the time of this writing. Pakistan's experience in transforming its financial sector may therefore be of general relevance, besides being of importance in itself for the functioning of one of the larger and more populous developing economies. The data set is sufficiently rich that it will be possible to assess the effects of the reforms on the banking system as a whole, and on sections of the industry, such as state-owned banks and privatized banks.

The next section outlines the recent evolution of the Pakistani banking system and the reforms introduced starting in the late 1980s. The following section explains the estimation procedures used and defines the data set. In the fourth section estimation results are presented, and the final section concludes.

\section{The Evolution of the Pakistani Banking System}

In the pre-reform period, the activites of the financial sector in Pakistan were largely directed by the government as a means to implement its development strategy. The domestic banks had all been nationalized in 1974 and were consolidated into six major national commerical banks,; in addition, several specialized credit institutions and household savings schemes were established. About 25 foreign banks operated, but their market share was relatively small. Banks were given detailed instructions on the allocation of credit to specific sectors, and a plethora of administrative interest rates were set for various purposes. Fees were also regulated in detail. Yet prudential regulation, and in particular capitalization and provisioning requirements, were weak. In this environment, banks had little incentive and scant means to mobilize additional savings, reduce operating costs, or make lending decisions based on creditworthiness.

The financial market reforms were initiated in the late 1980s (more information is available in Khan and Aftab (1994), Ul-Haque and Kardar (1995), and Ul-Haque (1997), and in various issues of the Annual Report of the State Bank of Pakistan). The system of administered interest rates was streamlined and loosened starting in 1989-90. The share of credit directed to particular sectors was reduced in 1989, and bank-by-bank credit ceilings eliminated in 1992. New prudential regulations were introduced in 1989 and strengthened in 1992, while the State Bank of Pakistan (the central bank) enhanced its supervisory capacity. A system of auctioning government securities was established, and regular auctions for sixmonth bills and longer term bonds began in 1991 (see Hardy, 2000).

Along with these efforts at deregulation, the authorities sought to liberalize access to the financial sector by licensing private banks starting in 1992. In addition, two state-owned banks (Muslim Commercial Bank and Allied Bank of Pakistan) were privatized in 1991-92. ${ }^{3}$

\footnotetext{
${ }^{3}$ Plans to privatize more state-owned banks were under discussion but not put into effect.
} 
By 1997 there were still four major state-owned national commercial banks, but they faced competition from 21 domestic banks (including the two privatized banks) and 27 foreign banks.

The transformation of the Pakistani financial system was profound, but the role of the state remained important, not only through the national commercial banks, but also the specialized credit instiutions and sundry measures promoting the allocation of credit to certain favored sectors and facilitating the financing of the government. Further, significant non-prudential regulations remained in force, notably in relation to foreign exchange and external transactions.

\section{ESTIMATION SPECIFICATION}

\section{A. Measurement of Changes in Bank Efficiency}

The many regulatory and other structural changes affecting the financial sector in Pakistan during 1988-1992 had a significant impact on the behavior of banking institutions there. The entry of new, private banks and the lifting of restrictions on banking operations gave all institutions greater scope and stronger incentives to cut costs and generate revenue, even as intensified competition might have driven down monopoly rents. One might hope that these reforms led to an improvement in the efficiency of the banking system, where such an improvement can be achieved both by the initially less efficient institutions catching up with those using best practices, and by a general advance involving even the most efficient operators. It will be particularly important to identify effects on pre-existing, originally stateowned institutions (and especially those that were privatized), which remained very important and were subject to different constraints than those on new entrants. Allowance must also be made for changes in exogenous conditions, such as the prevailing macroeconomic situation. Therefore, to estimate the effects of the banking sector reforms, one needs first to be able to estimate the frontier of most efficient practices prevalent at each

point in time as a function of relevant exogenous variables, and how far from this frontier are the efficiency levels of different institutions or categories of institutions. One can then measure how the frontier shifts over time (due to structural changes or movements in the exogenous variables), and how the position of institutions relative to the frontier evolves. Since the reforms could have quite different effects on cost efficiency, revenue efficiency, and profitability, similar exercises need to be undertaken for each of these three concepts.

The particular approach used here is to specify a relationship between profits, costs or revenue and input and output prices that reflects optimizing behavior at the frontier of efficient practices, and then to add terms that capture deviations from best practices. One can then estimate how this frontier relationship is affected by the financial sector reforms, and how these deviations, or measures of relative "X-inefficiency," vary across institutions and 
over time. ${ }^{45}$ For example, the standard profit function can be augmented and written in logarithmic form as

$$
\ln \left(\pi_{b t}+\theta\right)=\mathrm{f}_{\pi}\left(p_{t}, w_{t}, z_{b t}, v_{t}\right)+\ln u_{\pi b}+\ln \varepsilon_{\pi b t}
$$

The function $\mathrm{f}_{\pi}$ represents optimizing behavior and relates the log of variable profits $\pi_{b t}$ of bank $b$ at time $t$ (plus a constant $\theta$ needed to insure that the argument is positive) to a vector of input prices $p_{t}$, a vector of variable input prices $w_{t}$, a vector of semi-fixed netputs $z_{b t}$, and possibly some environmental and structural variables $v_{t}$. The term $\varepsilon_{\pi b t}$ represents a random error that varies from period to period. The term $u_{\pi b}$ is a fixed effect that represents the reduction in bank $b$ 's profits due to persistent $\mathrm{X}$-inefficiency and is thus constant across the estimation period. The bank that has the highest $u_{\pi b}$ is presumed to be located on the profit efficiency frontier.

Based on this standard profit function, the relative inefficiency of bank $b$ can be measured as the ratio of the predicted profits of that bank to the predicted profits of a best-practice bank facing the same prices, using the same netputs, and under the same environmental conditions, net of random error. Specifically:

$$
\Pi E_{b t}=\frac{\hat{\pi}_{b}}{\hat{\pi}_{\max }}=\frac{\exp \left[\hat{f}_{\pi}\left(p_{t}, \mathrm{w}_{\mathrm{t}}, \mathrm{z}_{\mathrm{bt}}, \mathrm{v}_{\mathrm{t}}\right)+\ln \hat{\mathrm{u}}_{\pi \mathrm{b}}\right]-\theta}{\exp \left[\hat{f}_{\pi}\left(p_{t}, \mathrm{w}_{\mathrm{t}}, \mathrm{z}_{\mathrm{bt}}, \mathrm{v}_{\mathrm{t}}\right)+\ln \hat{\mathrm{u}}_{\pi \max }\right]-\theta},
$$

where $\ln \hat{u}_{\pi \max }$ is the maximum estimated value of $\ln u_{\pi b}$ obtained in the sample. This measure of relative inefficiency can then be averaged across banks or a subset of banks.

This measure of profitability assumes that the frontier and relative efficiency are constant over time. Yet profitability and absolute profit efficiency will inevitably change, in part because the financial sector reforms could shift the frontier and affect efficiency in the banking sector. To address this issue, the relative $\mathrm{X}$-inefficiency of different banks or groups of banks can be measured by evaluating (2) in various sub-periods.

In addition, one can compare the position of the whole frontier across periods. Denoting two periods of interest by $s$ and $t$, one can start by from the definition of the change in average productivity in terms of the efficiency frontier as:

\footnotetext{
${ }^{4}$ This econmetric approach allows one to separate out the effects of different exogenous factors such as output prices or structural variables, something which is not possible using a simple comparison of financial ratios.

${ }^{5}$ Berger and Humphrey (1997) provide a survey of a large number of studies of bank efficiency based on this approach.
} 


$$
\text { Change }_{\Pi}=\frac{\hat{\Pi}_{t}\left(X_{t}\right)}{\hat{\Pi}_{s}\left(X_{s}\right)} \text {, }
$$

where $\hat{\Pi}_{\tau}\left(X_{\tau}\right)$ is the estimated average practice profit function in period $\tau(\tau=s, t)$ given the explanatory variables $X_{\tau}$. This change in profitability will reflect in part variation in the exogenous variables, which might be termed business conditions. The change will also reflect shifts in structural conditions, such as productivity and the nature of market competition, which will be captured in the functional form of the profit function. ${ }^{6}$ To this end the change in profitability can usefully be broken down as:

$$
\text { Change } e_{\Pi}=\frac{\hat{\Pi}_{t}\left(X_{t}\right)}{\hat{\Pi}_{s}\left(X_{s}\right)}=\frac{\hat{\Pi}_{s}\left(X_{t}\right)}{\hat{\Pi}_{s}\left(X_{s}\right)} \times \frac{\hat{\Pi}_{t}\left(X_{t}\right)}{\hat{\Pi}_{s}\left(X_{t}\right)} .
$$

The first term on the right-hand side of the equation measures the proportional change in profits due just to changes in the exogenous variables, and assuming that the banking sector had continued with the same practices, regulations, and so forth, as captured in the estimated parameters of the profit equation. This term thus reflects the effect on profitability of changes in business conditions from period $s$ to period $t$, keeping structural features fixed. The second term reflects the changes in technology and market structure, keeping prices and other elements of business conditions fixed. Any effects on profitability of the financial sector reforms should appear primarily through this term. To obtain an overall measure of the changes, the various profit terms in equation (3) are projected for all the banks in each subsample and then averaged. ${ }^{7}$

The standard profit function is applicable if firms are price takers in all markets, output prices are well measured, and output is readily variable (see Berger and Mester, 1997). When these conditions are not met, it is more appropriate to concentrate on the alternative profit function, which can be defined by:

$$
\ln \left(\pi_{b t}+\theta\right)=f_{a}\left(y_{b t}, w_{t}, z_{b t}, v_{t}\right)+\ln u_{a b}+\ln \varepsilon_{a b t},
$$

where (besides variables already defined) $y_{b t}$ is the output of bank $b$ at time $t$, and the fixed effect capturing $\mathrm{X}$-inefficiency is $u_{a b}$. A measure of relative efficiency can be defined analagous to that for the standard profit function, and the change in profitably over time can again be broken down into the effects of changes in structural and business conditions.

\footnotetext{
${ }^{6}$ This nomenclature is slightly misleading, in that the structural reforms could affect the level and structure of interest rates, which are captured under "business conditions."

${ }^{7}$ One cannot take an average of ratios because the number of observations differs across subperiods.
} 
Financial sector reform might have a modest impact on bank profitability if, for example, greater pressure to achieve cost efficiency were offset by more intense competition and lower margins. The welfare gain from financial sector reform may accrue not so much to bank shareholders, as to the users of bank services. Hence, it is worthwhile to consider the effects of reform on both costs and revenues. ${ }^{8}$ The cost function:

$$
\ln \left(C_{b t}\right)=\mathrm{f}_{\mathrm{C}}\left(y_{b t}, w_{t}, z_{b t}, v_{t}\right)+\ln u_{C b}+\ln \varepsilon_{C b t}
$$

has been the focus of numerous studies of bank efficiency. The cost function can be estimated similarly to the profit function, but efficiency is measured relative to $\hat{u}_{C \min }$, that is, the lowest value of $u_{C b}$ obtained in the sample from the bank with the best practices in cost minimization. Specifically:

$$
C E f_{b t}=\frac{\hat{C}_{\min }}{\hat{C}_{b}}=\frac{\exp \left[\hat{f}_{C}\left(p_{t}, \mathrm{w}_{\mathrm{t}}, \mathrm{z}_{\mathrm{bt}}, \mathrm{v}_{\mathrm{t}}\right)+\ln \hat{\mathrm{u}}_{C \min }\right]}{\exp \left[\hat{f}_{C}\left(p_{t}, \mathrm{w}_{\mathrm{t}}, \mathrm{z}_{\mathrm{bt}}, \mathrm{v}_{\mathrm{t}}\right)+\ln \hat{\mathrm{u}}_{C b}\right]}=\frac{\hat{\mathrm{u}}_{C \min }}{\hat{\mathbf{u}}_{C b}}
$$

Similarly, the indirect revenue function:

$$
\ln \left(R_{b t}\right)=\mathrm{f}_{\mathrm{R}}\left(y_{b t}, w_{t}, z_{b t}, v_{t}\right)+\ln u_{R b}+\ln \varepsilon_{R b t}
$$

can be estimated, so that relative revenue efficiency can be assessed, and the change in revenue decomposed.

\section{B. Data Sample and Definitions of Variables}

Data were obtained from various editions of the publication Money and Banking Statistics issued by the State Bank of Pakistan, which contain annual information on the main balance sheet entries and revenue and expense items for all banks operating in Pakistan. The full sample covered the period from 1981 through $1997 .{ }^{\circ}$ It will be useful to divide the sample into two sub-periods, the first covering the years 1981-1992 before and during reform, and

\footnotetext{
${ }^{8}$ Studies of banking sector efficiency have tended to concentrate on the cost function rather than the revenue function; Berger, Humphrey, and Pulley (1996) is an exception. Looking at both in order facilitates the interpretation of the various effects of financial sector reform, even if the profit function is also estimated.

${ }^{9}$ Even if more recent data were available, it may not be useful for the purposes of this study because renewed macroeconomic difficulties in 1998 led to substantial changes in the regulatory regime.
} 
the second 1993-1997, by when the major reforms should have begun to take effect. ${ }^{10}$ Data were collected on 33 licensed banks for which adequate time series were available; several specialized credit institutions were excluded from the sample, as they were subject to different regulations and may have operated in distinct markets. The sample includes seven state-owned banks, of which two were privatized in 1991-92, 22 foreign banks, and 4 wholely private domestic banks, for which reliable data begin in $1993 .{ }^{11}$ The published data were corrected for a number of manifestly typographical errors (for example, when total assets did not equal total liabilities, or when one observation on a series different by an order of magnitude from the values observed in preceding and subsequent years); even so a small number of outliers were identified and deleted, leaving a total sample of 389 observations. The data set is used to define the needed variables, namely, profits, revenue and costs; a measure of bank output; relevant prices; and certain control variables. The variables used are summarized in Table 1.

Revenues (REVS) are defined as total interest and fee receipts, and total variable costs $(C O S T)$ are the sum of interest costs and fees, and other wage and non-wage operating expenses. Profits $(P R O F)$ are measured by the difference between these revenue and the total costs. All bank-specific variables except prices were dividing by total assets in order to normalize for differences in size between institutions and trend nominal growth. ${ }^{12}$ Furthermore, the dependent variables can then be roughly equated with common measures of bank performance; for example, the variable PROF corresponds to the return on assets.

\footnotetext{
${ }^{10}$ The first sub-period could be further divided into a pre-reform period $1981-87$, and a reform period 1988-1992. The results of interest turned out not to be qualitatively very different when this refinement is adopted, and for the sake of concision not reported.
}

${ }^{11}$ Data on some private banks begins in 1992, but in most cases these banks were clearly not yet operational for the full year, and in particular their interest revenue and expenses accrued for only part of the year.

12 Many studies normalize relative to banks' capital, but in Pakistan capitalization and provisioning regulations were tightened considerably during the sample period, starting towards the end of the 1980s. In particular, the state-owned banks were severely undercapitalized in the earlier years, and over time were required to meet capitalization standards in line with international norms. Normalizing by capital would conflate these institutional changes with changes in bank behavior, and overstate profitability in the early years. 
Table 1. Variable Definitions and Summary Statistics 1/

\begin{tabular}{llrrrr}
\hline & & & & & \\
& & Standard & & \\
& & Mean & Deviation & Minimum & Maximum \\
& & & & & \\
\hline & & & & & \\
PROF & Profits/total assets & 2.27 & 1.58 & -2.05 & 9.19 \\
COST & Costs/total assets & 5.55 & 1.90 & 1.67 & 12.11 \\
REVS & Revenues/total assets & 7.82 & 2.47 & 2.62 & 16.58 \\
OUTP & Earning assets/total assets & 55.59 & 13.13 & 14.93 & 93.32 \\
$I N T R$ & Interest receipts/earning assets & 11.34 & 0.96 & 9.86 & 13.53 \\
$I N T C$ & Interest costs/earning liabilities & 6.36 & 0.73 & 5.38 & 8.43 \\
OTHC & Other costs/earning liabilities & 2.76 & 0.26 & 2.18 & 3.09 \\
$C P R S$ & Capital and reserves/total assets & 3.91 & 2.13 & 0.65 & 17.44 \\
$D E P B$ & Interbank borrowing/deposits & 21.26 & 29.05 & 0.00 & 235.47 \\
& & & & & \\
\hline
\end{tabular}

1/ Based on full sample excluding outliers. 
A question that arises in the study of bank productivity concerns how to identify bank output. Banks generally provide a variety of intermediation and transaction services, and often these activities are bundled together. For example, depositors provide funds as an input to a bank's lending activities, but also use the bank to make payments. Thus, the volume of deposits is possibly a good indicator of the bank's output of transaction services. Furthermore, when the return on the deposited funds consists primarily of low-cost transaction services, the cost to the bank of this input may appear in large part as non-interest operating expenses. On the asset side, some banks may be relatively specialized in lending to enterprises, others in retail business, and some may be engaged mainly in interbank lending and the holding of securities. The question of how to identify a bank's inputs and outputs is not fully answerable given the limitation of available data, but does suggest that a fairly comprehensive indicator of bank activity is appropriate. In this study, a bank's output (denoted by $O U T P$ ) is proxied by its total earning assets, which comprise loans and advances, holdings of government securities and bills purchased and discounted, cash balances with other banks, and other investments.

The unit price of banks' output (denoted by INTR) is defined as total income from interest receipts and fees, divided by earning assets. The unit price of borrowed funds (INTC) is defined as total interest expenses and fees divided by payable liabilities, namely deposits and amounts due to other banks, which are taken to be inputs. A further distinction between different financial prices is not possible because interest and fees are aggregated on both the revenue and expenses sides in the reported data, and loan loss provisions are not separated from other non-specified costs. ${ }^{13}$ No data were available on the number of employees or the volume of fixed assets, so it was not possible to measure labor costs per employee or facility costs per unit of property, which might in any case vary between banks due to variations in quality. Moreover, non-interest operating costs may be incurred mainly in providing nonremunerated services to depositors, that is, in obtaining funds as inputs. Therefore noninterest unit costs are estimated as wage costs, rent, depreciation, directors' and auditors' fees, and sundry operating expenses, divided by payable liabilities (these other costs are denoted by $O T H C){ }^{14} 15$

${ }^{13}$ In any case banks may take charges for loan losses in a "lumpy" manner, and therefore it may be difficult to assign loan losses to particular years. When regulations were tightened in Pakistan starting in 1989, banks had to made a stock adjustment in provisions for losses incurred over many past years.

${ }^{14}$ What are termed "other revenue" and "other expenses" in the data source are excluded on the assumption that they represent non-variable costs, such as capital gains on the disposal of assets or losses incurred in the past on impaired loans.

${ }^{15}$ One might want to exclude depreciation and rent from variable costs, but in the data set used here these items are conflated with other items such as lighting and telephone charges, which are variable costs. All these items are relatively small. 
The only netput included was the sum of each bank's capital and reserves (CPRS), which provide an alternative to deposits and interbank borrowing in the financing of the bank's operations. The unit prices of inputs and outputs are assumed to be the same for all banks (consistent with the assumption that banks are price takers, at least in the market for inputs) and are therefore measured on an aggregate basis, that is, by dividing aggregate receipts or expenses by aggregate quantitites. ${ }^{16}$

A number of variables were included to capture relevant environmental or structural factors. Some experimentation suggested that the ratio of funds borrowed from other banks (termed "due banks" in the data source) to deposits, which will be denoted by $D E P B$, frequently added to the explanatory power of the model. This variable captures differences between banks in the degree of specialization in retail business; $D E P B$ will tend to be low for a bank with an extensive branch network from which it can gather deposits, and high for banks that concentrate on wholesale business. When the model is estimated across the full sample, it was also useful to include a dummy variable taking on the value of one during the second sub-period (SP2), which allows at least the intercept to vary over time. Other candidate variables that might proxy for environmental or structural factors include banks' market share, their loan to deposit ratios, the real rate of growth of GDP, and official interest rates. However, when included in the regressions, the estimated coefficients on these variables were found to be predominantly statistically insignificant, and hence they were dropped to save degrees of freedom.

The evolution over time of some of the main variables are illustrated in the figures. Figure 1 shows that the average unit price of output INTR and the average unit cost of funds INTC were both fairly stable at around 11 percent and 6 percent, respectively, for the period before and during reform, but began to rise thereafter, though the spread was roughly constant. Variation in unit non-interest costs $O T H C$ was slight, which may make it difficult to determine accurately the role of this variable in the profit, cost, and revenue functions.

\footnotetext{
${ }^{16}$ To allow for the possibility that banks may be facing segmented market for inputs or output, regressions were rerun using bank-specific prices; the results for the alternative profit function are reported below.
} 


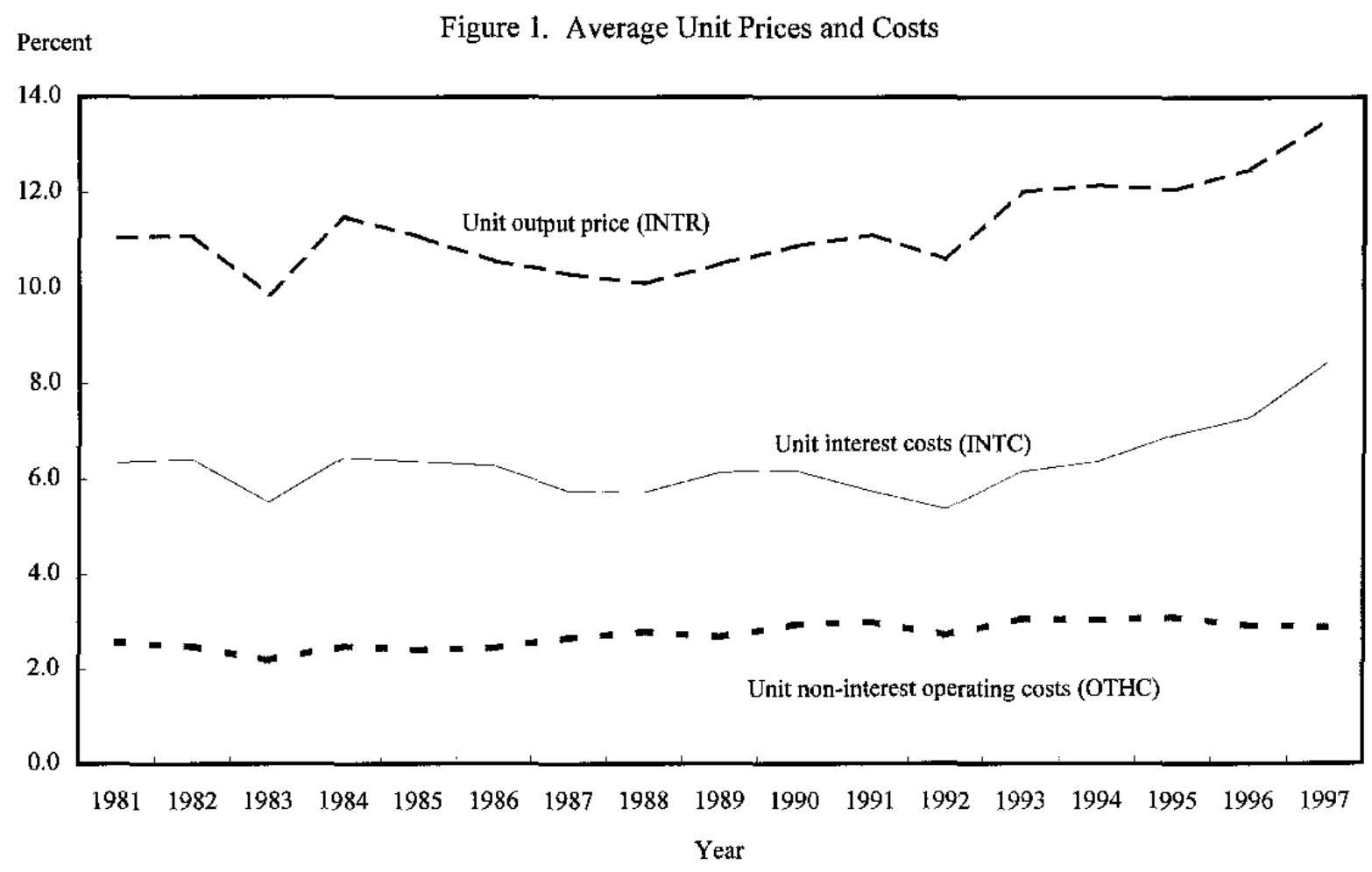


Figures 2 and 3 depict the paths of revenues and costs for different categories of banks, relative to their total assets; ${ }^{17}$ profits are just the difference between these two series. The most striking trend is that the financial market reforms seem to have led to a sharp rise in both revenues and costs for all banks. The foreign banks initially had relatively low costs, but seem to have converged following the reforms. The banks that were privatized do not appear to have been very different from the other public sector banks before the reforms, but subsequently their revenues rose relatively quickly. The new private banks started in 1993 with comparatively low costs and low revenues, but quickly caught up and soon generated more revenue per unit of assets than any other category of bank. ${ }^{\text {is }}$

Concerning other variables of interest, the low level of capitalization of the state-owned banks is shown in Figure 4. The private banks started with high levels of capital and reserves, but the public sector banks and in particular the foreign banks increased their capitalization significantly in the last sub-period. Surprisingly, the data suggest that the privatized banks did not participate in this tendency; perhaps their assets had a lower risk rating than those of the other public sector banks, and therefore they needed less capital and reserves. Figure 5 illustrates the path of the variables $D E P B$ for the various bank categories. In the pre-reform period the foreign banks were clearly heavily dependent on interbank funding, but increased their access to deposits thereafter. The public sector banks usually undertook little interbank borrowing; they presumably could collect ample deposits from households and enterprises and were the source of funds for other banks. The private banks were, at least initially, moderately active borrowers in the interbank market.

${ }^{17}$ Each observation is the unweighted arithmetic mean of the relevant ratios in that period for the banks belonging to the category.

${ }^{18}$ U1-Haque and Kardar (1995) contain a further discussion of the balance sheet and revenue and expenses ratios of banks in Pakistan. 
Figure 2. Revenue to Total Asset Ratios

(in percent)

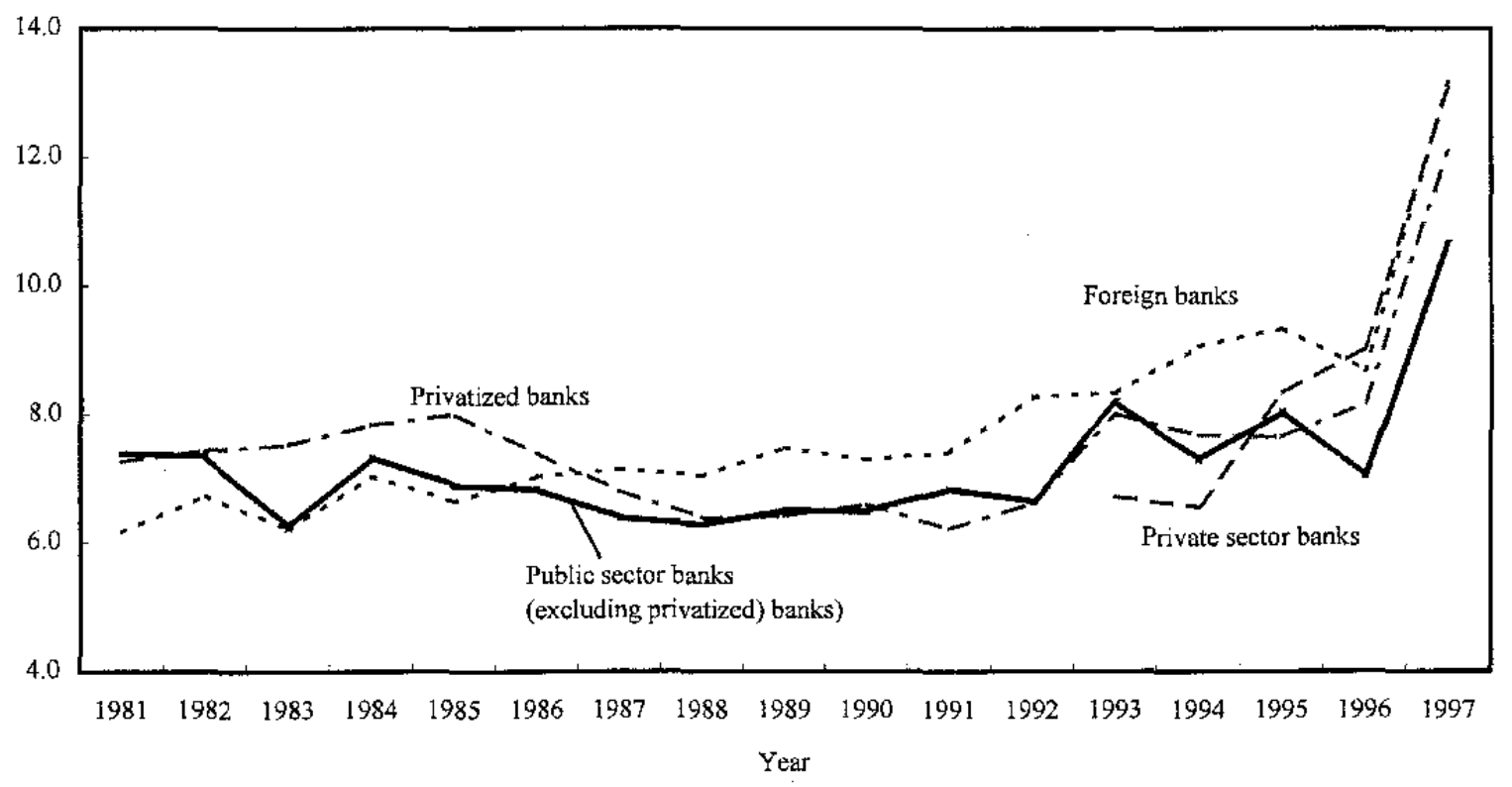

Figure 3. Costs to Total Asset Ratios

(In percent)

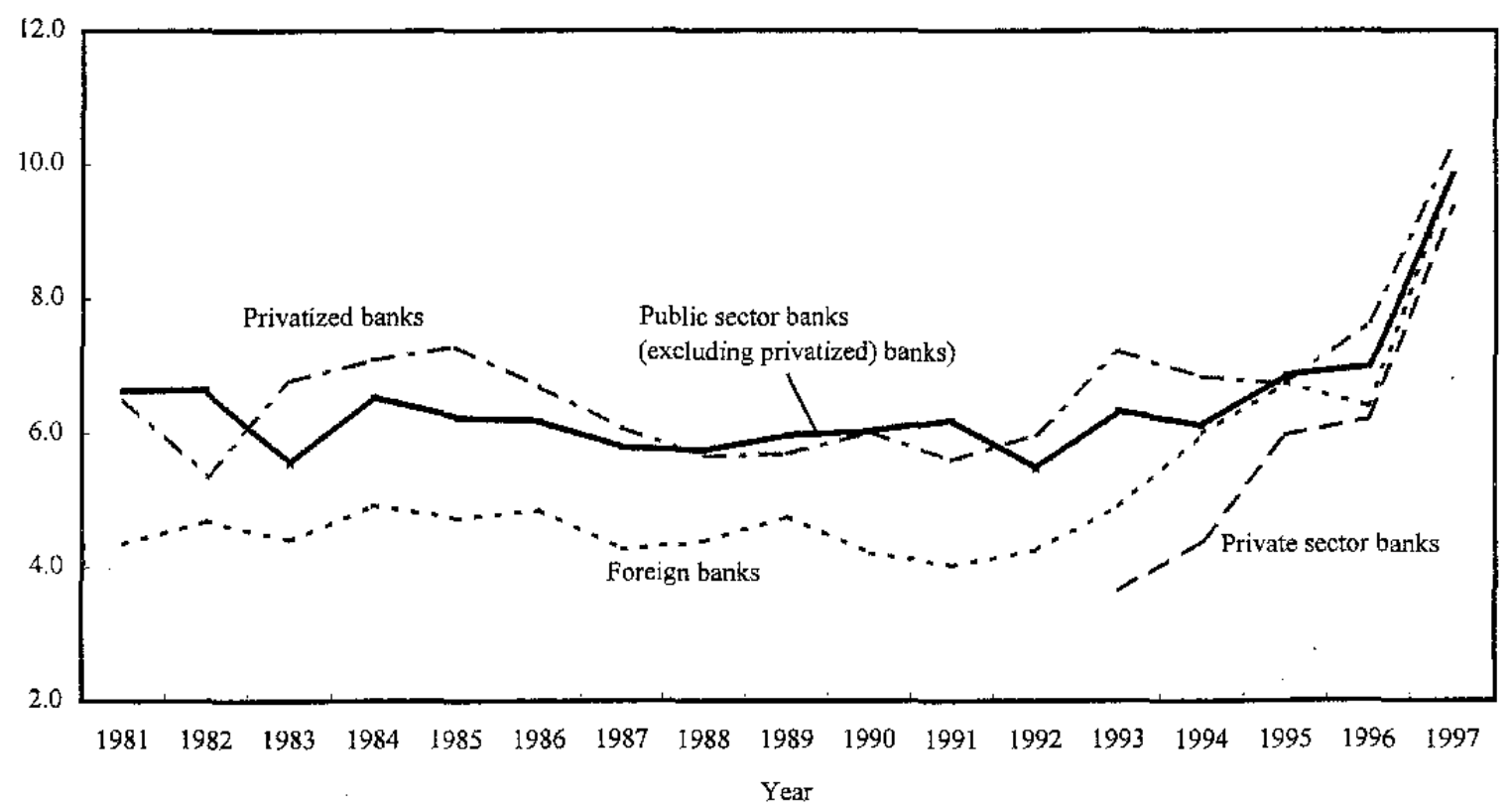


Figure 4. Capital and Reserves to Total Asset Ratios (In percent)

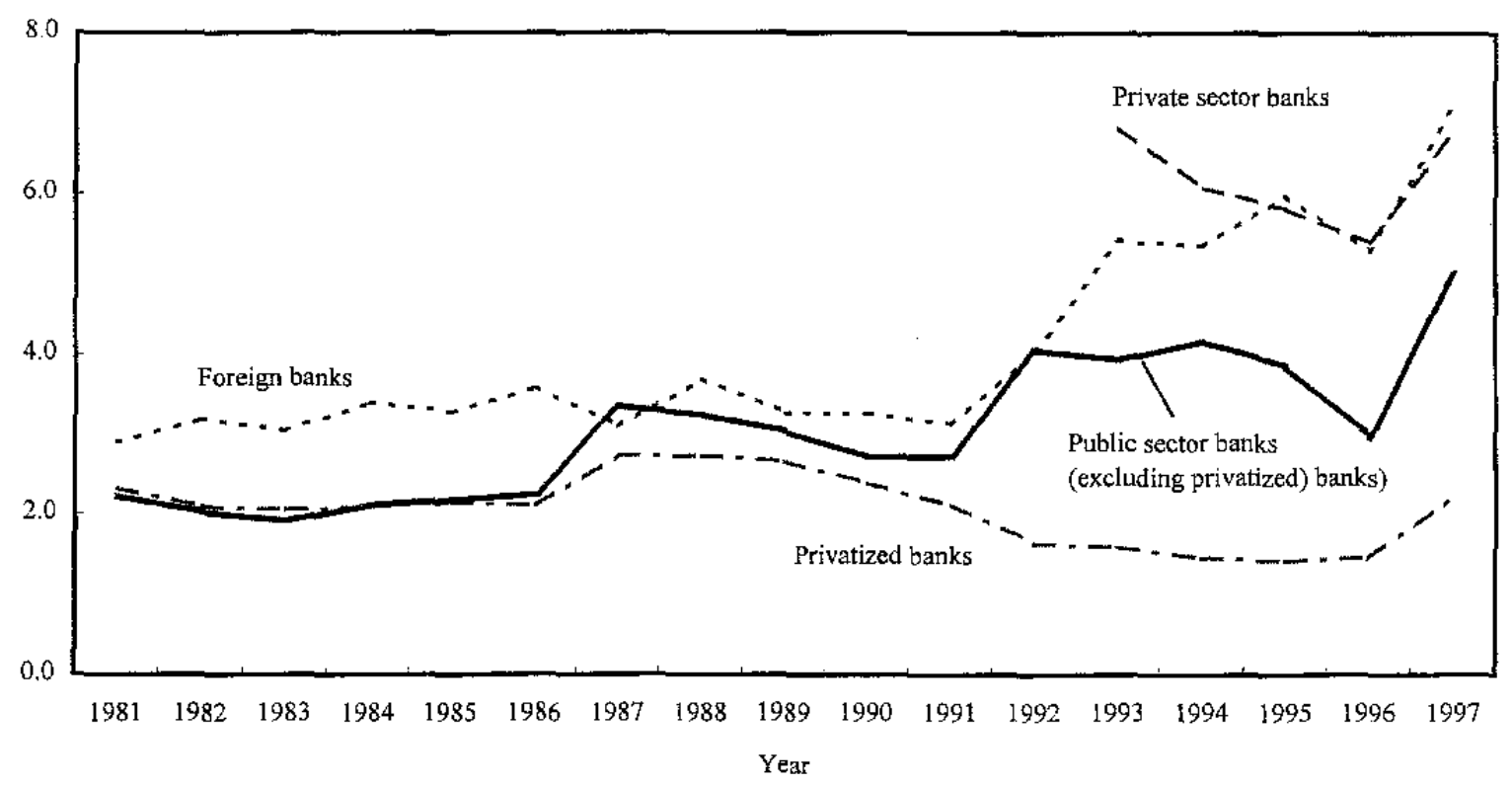

Figure 5. "Due Banks" to Deposits Ratios

(In percent)

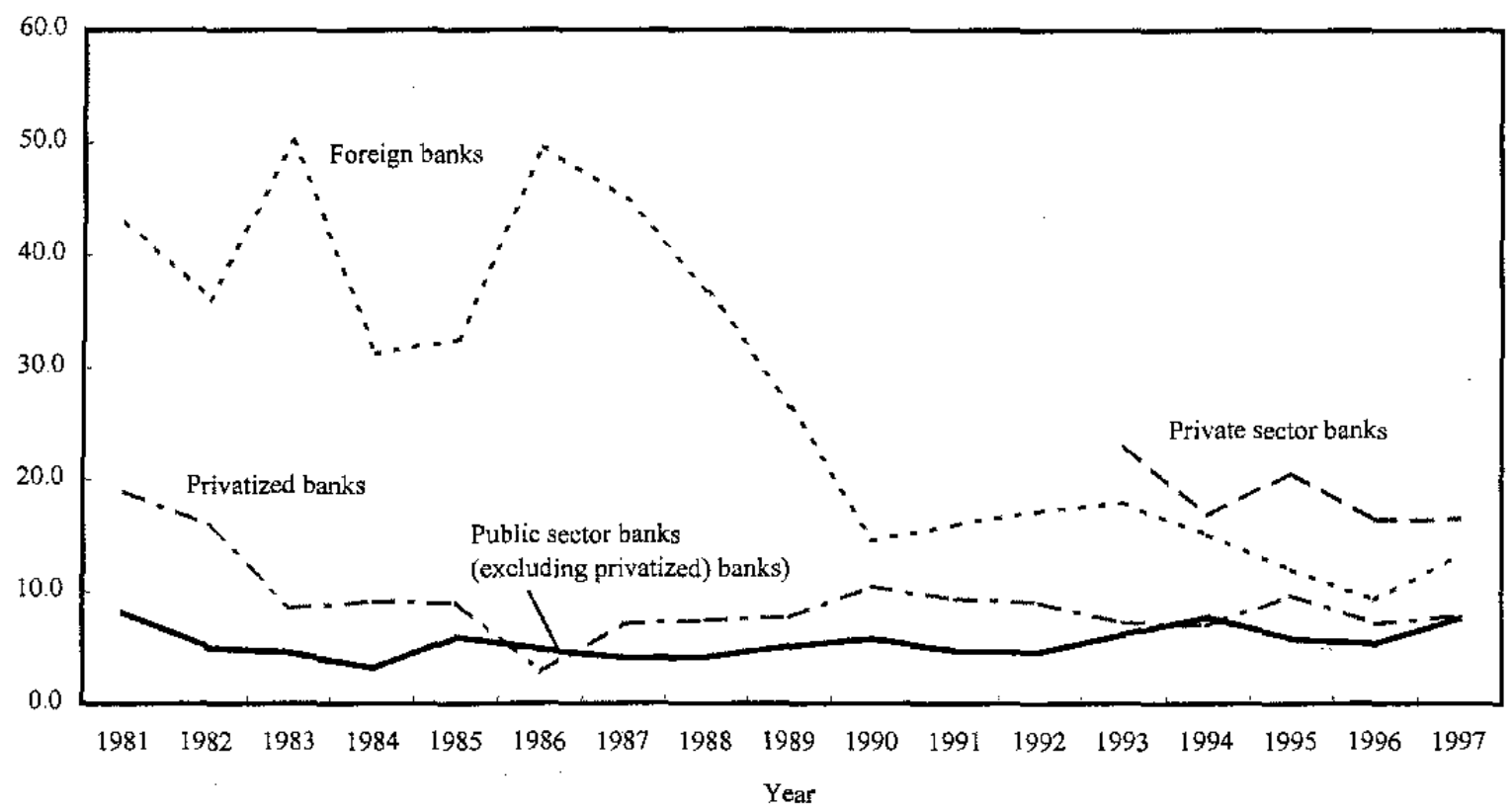




\section{Model Specification and Estimation}

The available data is sufficient to allow the estimation of the various measures of efficiency described above and the changes in these measures. The two profit functions and the revenue and cost functions that form the basis for these measures are made operational by adopting a translog functional form (the limited number of observations available preclude the adoption of a more flexible specification that would have used more degrees of freedom). Thus, for the full sample, the standard profit function $f_{\pi}\left(p_{t}, w_{t}, z_{b t}, v_{t}\right)$ to be used in equation (1) is assumed to take the form:

$$
\begin{aligned}
\beta_{0}+ & \beta_{1} \ln (I N T R)+\beta_{2} \ln (I N T R)^{2}+\beta_{3} \ln (I N T C)+\beta_{4} \ln (I N T C)^{2}+\beta_{5} \ln (\text { OTHC }+ \\
& \beta_{6} \ln (\text { OTHC })^{2}+\beta_{7} \ln (C P R S)+\beta_{8} \ln (C P R S)^{2}+\beta_{9} \ln (I N T R) \ln (I N T C)+ \\
& \beta_{10} \ln (I N T R) \ln (\text { OTHC })+\beta_{11} \ln (I N T R) \ln (C P R S)+\beta_{12} \ln (I N T C) \ln (\text { OTHC })+ \\
& \beta_{13} \ln (I N T C) \ln (C P R S)+\beta_{14} \ln (\text { OTHC }) \ln (C P R S)+\beta_{15} \ln (D E P B)+\beta_{16} S P 2,
\end{aligned}
$$

which includes one output price, the two input prices, one netput, and all the cross products, plus two variables capturing structural and environmental factors; time and bank subscripts have been dropped for clarity. The right-hand sides of the equations for the alternative profit function, revenue, and costs are similar, except that output quantities OUTP replace output prices $I N T R$. When estimating over sub-periods, a more parsimoneous specification is needed, because the unit price terms are constant across banks in each year, and therefore only a limited number of individual, industry-wide coefficients can be identified when the sample covers only a small number of years. Hence, for this purpose the quadratic terms in unit prices (with coefficients $\beta_{2}, \beta_{4}$, and $\beta_{6}$ in the profit function) were dropped. The constant $\theta$ introduced into the left-hand side of the profit equations to be able to take logs even when profits were negative was set equal to the minimum profit observed in the sample, plus unity; with this dataset, $\theta=3.05$.

There are various approaches to estimation of efficiency frontiers and X-efficiency (Bauer, Berger, Ferrier, and Humphrey (1998) provide a recent overview). The choice of technique used here was dictated by the available data set, which consists of a panel with relatively few observations in some years. The variables that are measured comprise mostly financial stocks and flows, rather than quantities (such as number of employees), yet the possibility of errors in measurement must be recognozed. The "distribution free" approach seemed most suited to these circumstances. Specifically, a dummy variable for each bank is included to capture the "fixed effect" of bank-specific deviations from optimizing behavior, and the equation is estimated using a panel of data from a subsamples over which efficiency and technology are 
assumed to be stable. ${ }^{19}{ }^{20}$ In this way a reasonable number of degrees of freedom are available to estimate each equation, and the distributional assumptions are relatively weak.

In addition, it is interesting to trace the average behavior of some sub-set of banks (say, those that are state-owned) over time. To this end, rather than estimating bank-specific fixed effects, it is possible to estimate the average deviation from the efficency frontier of the subset and test for significance by including a dummy variable identifying the banks of interest in the relevant time period.

Equation (1) (or the other analogous equations) represents an efficiency frontier, and could therefore give rise to non-normal error terms. Furthermore, a preliminary examination of the data suggested that the distribution of residuals generally displayed leptokurtosis and, especially for the profit functions, skewness (evidence on this point will be presented). Because of the strong possibility that the errors will be non-normally distributed, the least absolute deviation (LAD) estimator was used. Examples of results obtained by Ordinary Least Squares (OLS) will also be reported for comparison purposes.

${ }^{19}$ The term "distribution free" indicates that no strong assumption is made concerning the distribution of the error terms, even though in principle the deviations from an efficiency frontier should be asymmetric. The distribution free approach is, however, fully parametric.

${ }^{20}$ In studies of the U.S. banking system, such as those cited above, the equation is often estimated cross-sectionally for each period separately, and the error term for each bank is averaged across periods to obtain an estimate of that bank's efficiency. The panel estimation procedure adopted here was dictated by the relatively small number of banks in Pakistan. Schmidt and Sickles (1984) and Cornwell, Schmidt, and Sickles (1990) establish that including (possibly time-varying) bank-specific effects in panel estimation of profit, revenue or cost functions yields consistent estimators if the structural conditions and in particular technology is constant across the time period covered by the sample. 


\section{RESULTS}

\section{A. Equation Estimates}

Tables 2 provides the result of the estimation of the various profit, cost and revenue functions. Results in the first two parts of the table are based on the different sub-periods but covering all the banks, and including a fixed effect for each bank. The overall fit is always satisfactory; higher $\mathrm{R}^{2}$ statistics are achieved for the cost and revenue functions than for the profit functions, and the alternative profit function seems to be somewhat better estimated than the standard profit function. The individual parameter estimates are difficult to interpret because of the collinearity inherent in the translog specification; often the estimated coefficients on cross-product terms (for example of interest costs and other costs) are more significant than those on individual variables alone. The fixed effects, which provide a measure of relative efficiency, are always jointly highly significant. In the first sub-period, banks with higher capitalization tend to be more profitable, primarily due to lower costs (CPRS enters with a negative coefficent in the cost function), and banks that rely on a large deposit base tend to be less profitable, as shown by the negative coefficent on $D E P B$, perhaps because they are more heavily commited to retail banking, where margins are lower. These effects seem to dissipate in the second sub-period.

The third section of the table presents the results of OLS estimation for the second subperiod. The $\mathrm{R}^{2}$ statistics (which OLS effectively maximizes) are only slightly higher than those of the LAD estimates, while the Jarque-Bera and Shapiro-Wilk test statistics for the normality of the error terms are all highly significant, which suggests that LAD estimation is more appropriate for this data set than is OLS estimation. The estimated coefficients usually have the same sign as the LAD coefficients, but tend to be larger in absolute magnitude, and the standard errors are also larger, so slightly fewer significant coefficients are found.

An indication of the robustness of the estimates is provided by the results for the alternative profit function obtained under different specifications or samples, which are reported in the last section of Table 2 (similar results were obtained for the other dependent variables). The results obtained from the full sample resemble those from the first sub-sample. Estimating the full specification including all the quadratic terms (which is possible only with the added degrees of freedom in the full sample) yields a number of additional significant estimated ceoffieicents, but increases the $\mathrm{R}^{2}$ statistic only slightly, so the parsimoneous specification used generally in this paper seems satisfactory for our purposes. 
Table 2. Estimated Coefficients of Efficiency Frontiers

\begin{tabular}{|c|c|c|c|c|}
\hline \multirow[b]{2}{*}{ Function } & \multicolumn{4}{|c|}{ First Sub-Period } \\
\hline & Profit Function & Alternative Profit Function & Cost Function & Revenue Function \\
\hline Dependent variable & $\ln P R O F$ & $\ln P R O F$ & $\ln \operatorname{Cos} T$ & $\ln R E V S$ \\
\hline Estimation procedure & $\mathrm{LAD}$ & $\mathrm{LAD}$ & $\mathrm{LAD}$ & $\mathrm{LAD}$ \\
\hline Constant & $\begin{array}{c}8.318 \\
(19.884)\end{array}$ & $\begin{array}{c}-9.914 \\
(18.104)\end{array}$ & $\begin{array}{c}6.670 \\
(18.691)\end{array}$ & $\begin{array}{c}-8.757 \\
(18.955)\end{array}$ \\
\hline $\mathrm{Ln} I N T R$ & $\begin{array}{c}2.083 \\
(0.912)\end{array}$ & $\cdots$ & $\ldots$ & $\cdots$ \\
\hline $\mathrm{Ln} J N T R^{2}$ & $\ldots$ & $\ldots$ & $\ldots$ & $\cdots$ \\
\hline LnOUTP & $\ldots$ & $\begin{array}{l}-4.531 \\
(2.016)\end{array}$ & $\begin{array}{c}4.149 \\
(2.081) *\end{array}$ & $\begin{array}{l}-1.914 \\
(2.110)\end{array}$ \\
\hline LnOUTP ${ }^{2}$ & $\ldots$ & $\begin{array}{c}0.015 \\
(0.120)\end{array}$ & $\begin{array}{l}-0.079 \\
(0.124)\end{array}$ & $\begin{array}{l}-0.227 \\
(0.125)+\end{array}$ \\
\hline $\operatorname{LnINTC}$ & $\begin{array}{c}2.337 \\
(6,859)\end{array}$ & $\begin{array}{l}-9.630 \\
(6.312)\end{array}$ & $\begin{array}{c}1.786 \\
(6.516)\end{array}$ & $\begin{array}{l}-9.607 \\
(6.608)\end{array}$ \\
\hline $\mathrm{L} I N T C^{2}$ & $\cdots$ & $\cdots$ & $\cdots$ & $\cdots$ \\
\hline LnOTHC & $\begin{array}{c}1.019 \\
(5.319)\end{array}$ & $\begin{array}{c}2.773 \\
(4.704)\end{array}$ & $\begin{array}{c}5.381 \\
(4.856)\end{array}$ & $\begin{array}{l}-0.011 \\
(4.925)\end{array}$ \\
\hline $\operatorname{LnOTHC} \mathrm{C}^{2}$ & $\ldots$ & $\cdots$ & $\ldots$ & $\ldots$ \\
\hline LnCPRS & $\begin{array}{c}1.248 \\
(1.411)\end{array}$ & $\begin{array}{c}3.058 \\
(1.367) *\end{array}$ & $\begin{array}{l}-2,601 \\
(1.411)+\end{array}$ & $\begin{array}{c}1.275 \\
(1.431)\end{array}$ \\
\hline $\mathrm{LnCPRS^{2 }}$ & $\begin{array}{l}-0,005 \\
(0,038)\end{array}$ & $\begin{array}{c}0.032 \\
(0.045)\end{array}$ & $\begin{array}{c}0.074 \\
(0.047)\end{array}$ & $\begin{array}{c}0.008 \\
(0.047)\end{array}$ \\
\hline LnINIR.LnCPRS & $\begin{array}{l}-1.118 \\
(0.756)\end{array}$ & $\ldots$ & $\ldots$ & $\ldots$ \\
\hline LnOUTP $\operatorname{Ln} I N T C$ & $\ldots$ & $\begin{array}{c}0.006 \\
(0.525)\end{array}$ & $\begin{array}{l}1.309 \\
-0.542 *\end{array}$ & $\begin{array}{l}0.684 \\
-0.549\end{array}$ \\
\hline LnOUTP.LnOTHC & $\cdots$ & $\begin{array}{l}-1.339 \\
(0.388) * *\end{array}$ & $\begin{array}{l}-0.141 \\
(0.400)\end{array}$ & $\begin{array}{l}-1.660 \\
(0.406) * *\end{array}$ \\
\hline LnOUTP .LnCPRS & $\cdots$ & $\begin{array}{l}-0.222 \\
(0.141)\end{array}$ & $\begin{array}{l}(0.030) \\
(0.146)\end{array}$ & $\begin{array}{c}0.083 \\
(0,148)\end{array}$ \\
\hline $\mathrm{Ln} / N T C, \mathrm{Ln} O T H C$ & $\begin{array}{c}0.779 \\
(1.872)\end{array}$ & $\begin{array}{l}-2.676 \\
(1.615)+\end{array}$ & $\begin{array}{c}1.635 \\
(1.667)\end{array}$ & $\begin{array}{l}-2.127 \\
(1.691)\end{array}$ \\
\hline $\operatorname{Ln} I N T C . \operatorname{LnCPRS}$ & $\begin{array}{l}-0.462 \\
(0.485)\end{array}$ & $\begin{array}{l}-0.624 \\
(0.308)^{*}\end{array}$ & $\begin{array}{l}-0.079 \\
(0.318)\end{array}$ & $\begin{array}{l}-0.437 \\
(0.323)\end{array}$ \\
\hline LnOTHC.LaCPRS & $\begin{array}{c}1.342 \\
(0.289) * *\end{array}$ & $\begin{array}{c}1.099 \\
(0.250)^{* *}\end{array}$ & $\begin{array}{l}-0.702 \\
(0.258) * *\end{array}$ & $\begin{array}{c}0.736 \\
(0.262) \text { ** }\end{array}$ \\
\hline $\operatorname{Ln} D F P_{B}$ & $\begin{array}{l}-0.076 \\
(0.014) * *\end{array}$ & $\begin{array}{l}-0.035 \\
(0.013)^{* *}\end{array}$ & $\begin{array}{l}-0.024 \\
(0.013)+\end{array}$ & $\begin{array}{l}-0.057 \\
(0.013) * *\end{array}$ \\
\hline $\mathrm{R}^{2}$ & 0.655 & 0.677 & 0.715 & 0.644 \\
\hline Adjusted $\mathrm{R}^{2}$ & 0.594 & 0.615 & 0,661 & 0.576 \\
\hline SSR & 6.940 & 6.522 & 5.92 .3 & 7.157 \\
\hline SD dependent variable & 0.285 & 0.285 & 0.288 & 0.283 \\
\hline SE of regression & 0.181 & 0.177 & 0.169 & 0.185 \\
\hline Mean absolute residuals & 0.111 & 0.104 & 0.108 & 0.109 \\
\hline No. of observations & 249 & 249 & 249 & 249 \\
\hline F test fixed effects $=0$ & $9.722 * *$ & $9.664^{* *}$ & $4.087^{* *}$ & $4.766 * *$ \\
\hline $\mathrm{F}(32,389)$ & 0.000 & 0.000 & 0.000 & 0.000 \\
\hline
\end{tabular}

Standard errors in parentheses. ${ }^{* *}$ denotes significance at at least the 1 percent level; ${ }^{*}$ denotes significance at at least at the 5 percent level;

+ denotes significance at at least the 10 percent level. 
Table 2 (Continued). Estimated Coefficients of Efficiency Frontiers

\begin{tabular}{|c|c|c|c|c|}
\hline \multirow[b]{2}{*}{ Function } & \multicolumn{4}{|c|}{ Second Sub-Period } \\
\hline & Profit Function & Aternative Profit Function & Cost Function & Revenue Function \\
\hline $\begin{array}{l}\text { Dependent variable } \\
\text { Estimation procedure }\end{array}$ & $\ln P R O F$ & $\ln P R O F$ & $\ln C O S T$ & $\ln R E V S$ \\
\hline Constant & $\begin{array}{c}-28.163 \\
(134.066)\end{array}$ & $\begin{array}{r}-234.116 \\
(86.471)\end{array}$ & $\begin{array}{l}-81.798 \\
(70.956)\end{array}$ & $\begin{array}{c}26.769 \\
(75.843)\end{array}$ \\
\hline $\mathrm{Ln} / N T R$ & $\begin{array}{c}4.582 \\
(2.572)+\end{array}$ & $\cdots$ & $\cdots$ & $\cdots$ \\
\hline $\mathrm{Ln} N N T R^{2}$ & $\cdots$ & $\cdots$ & $\cdots$ & $\cdots$ \\
\hline LnOUTP & $\cdots$ & $\begin{array}{l}-5.306 \\
(9.848)\end{array}$ & $\begin{array}{c}1.409 \\
(8.081)\end{array}$ & $\begin{array}{l}-.3 .877 \\
(8.638)\end{array}$ \\
\hline InOUTP ${ }^{2}$ & $\cdots$ & $\begin{array}{c}0.078 \\
(0.114)\end{array}$ & $\begin{array}{l}-0.372 \\
(0.094) * *\end{array}$ & $\begin{array}{l}-0.129 \\
(0.100)\end{array}$ \\
\hline $\mathbf{L n} I N T C$ & $\begin{array}{l}-20.427 \\
(48.569)\end{array}$ & $\begin{array}{l}-97.953 \\
(27.580) * *\end{array}$ & $\begin{array}{l}-27.667 \\
(22.632)\end{array}$ & $\begin{array}{c}2.413 \\
(24.190)\end{array}$ \\
\hline $\mathrm{Ln} I N T C^{2}$ & $\cdots$ & $\cdots$ & $\cdots$ & $\cdots$ \\
\hline $\mathrm{LnOTHC}$ & $\begin{array}{l}-10.560 \\
(37.495)\end{array}$ & $\begin{array}{l}-68.893 \\
(24,452) * *\end{array}$ & $\begin{array}{l}-21.551 \\
(20.065)\end{array}$ & $\begin{array}{c}9.479 \\
(21.447)\end{array}$ \\
\hline $\mathrm{LnOTHC}^{2}$ & $\cdots$ & $\cdots$ & $\cdots$ & $\cdots$ \\
\hline $\mathrm{LnCPRS}$ & $\begin{array}{l}.7 .581 \\
\{6,055)\end{array}$ & $\begin{array}{l}-6.582 \\
(4.418)\end{array}$ & $\begin{array}{l}13.362 \\
(3.412) * *\end{array}$ & $\begin{array}{c}5.382 \\
(3.647)\end{array}$ \\
\hline $\operatorname{LnC} P R S^{2}$ & $\begin{array}{c}0.055 \\
(0.050)\end{array}$ & $\begin{array}{c}0.035 \\
(0.048)\end{array}$ & $\begin{array}{l}-0.086 \\
(0.039) *\end{array}$ & $\begin{array}{c}0.014 \\
(0.042)\end{array}$ \\
\hline $\mathrm{Ln} N N T R, \mathrm{Ln} C P R S$ & $\begin{array}{l}-0.953 \\
(1.278)\end{array}$ & $\cdots$ & $\cdots$ & $\cdots$ \\
\hline $\operatorname{LnOUTP} \cdot \mathrm{Ln} / N T C$ & $\cdots$ & $\begin{array}{r}-0.531 \\
(0.666)\end{array}$ & $\begin{array}{c}0.010 \\
(0.546)\end{array}$ & $\begin{array}{c}0.273 \\
(0.584)\end{array}$ \\
\hline LnOUTP.LnOTHC & $\cdots$ & $\begin{array}{l}-1.001 \\
(2.424)\end{array}$ & $\begin{array}{l}-0.511 \\
(1.989)\end{array}$ & $\begin{array}{l}-I .840 \\
(2.126)\end{array}$ \\
\hline LnOUTP.LnCPRS & $\cdots$ & $\begin{array}{c}0.014 \\
(0.105)\end{array}$ & $\begin{array}{c}0.025 \\
(0.086)\end{array}$ & $\begin{array}{l}-0.186 \\
(0.092) *\end{array}$ \\
\hline $\mathrm{I} n I N T C$. InIOTHC. & $\begin{array}{c}-5.626 \\
(13.918)\end{array}$ & $\begin{array}{l}-28.579 \\
(8.029)^{* *}\end{array}$ & $\begin{array}{l}-7.794 \\
(6.588)\end{array}$ & $\begin{array}{c}1.007 \\
(7.042)\end{array}$ \\
\hline $\mathrm{Ln} / N T C . \mathrm{Ln} C P R S$ & $\begin{array}{l}-0.063 \\
(0.391)\end{array}$ & $\begin{array}{l}-0.477 \\
(0.288)\end{array}$ & $\begin{array}{l}1.385 \\
(0.236)^{* *}\end{array}$ & $\begin{array}{c}0.472 \\
(0.253)+\end{array}$ \\
\hline $\operatorname{Ln} O T H C \cdot \operatorname{LnCPRS}$ & $\begin{array}{l}-1.527 \\
(1.224)\end{array}$ & $\begin{array}{l}-1.474 \\
(1.022)\end{array}$ & $\begin{array}{l}2.679 \\
(0.839) * *\end{array}$ & $\begin{array}{c}0.944 \\
(0.896)\end{array}$ \\
\hline $\operatorname{Ln} D E P B$ & $\begin{array}{c}0.011 \\
(0.021)\end{array}$ & $\begin{array}{l}-0.029 \\
(0.022)\end{array}$ & $\begin{array}{c}0.023 \\
(0.017)\end{array}$ & $\begin{array}{l}-0.021 \\
(0.019)\end{array}$ \\
\hline $\mathrm{R}^{2}$ & 0.649 & 0.680 & 0.813 & 0.815 \\
\hline Adjusted $R^{2}$ & 0.517 & 0.546 & 0.735 & 0.737 \\
\hline SSR & 5.206 & 4.816 & 2.920 & 2.640 \\
\hline SD dependent variable & 0.324 & 0.324 & 0.333 & 0.318 \\
\hline SE of regression & 0.227 & 0.223 & 0.173 & 0.164 \\
\hline Mean absolute residuals & 0.097 & 0.095 & 0.078 & 0.083 \\
\hline No. of observations & 140 & 140 & 140 & 140 \\
\hline$F$ test fixed effects $=0$ & 4.430 & 4,580 & 2.150 & 4.488 \\
\hline$F(32,389)$ & 0.000 & 0.000 & 0.000 & 0.000 \\
\hline
\end{tabular}

Standard errors in parentheses. ${ }^{* *}$ denotes significance at at least the 1 percent level; ${ }^{*}$ denotes significance at at least at the 5 percent level; + denotes significance at at least the 10 pcrcent level. 
Table 2 (Continued). Estimated Coefficients of Efficiency Frontiers

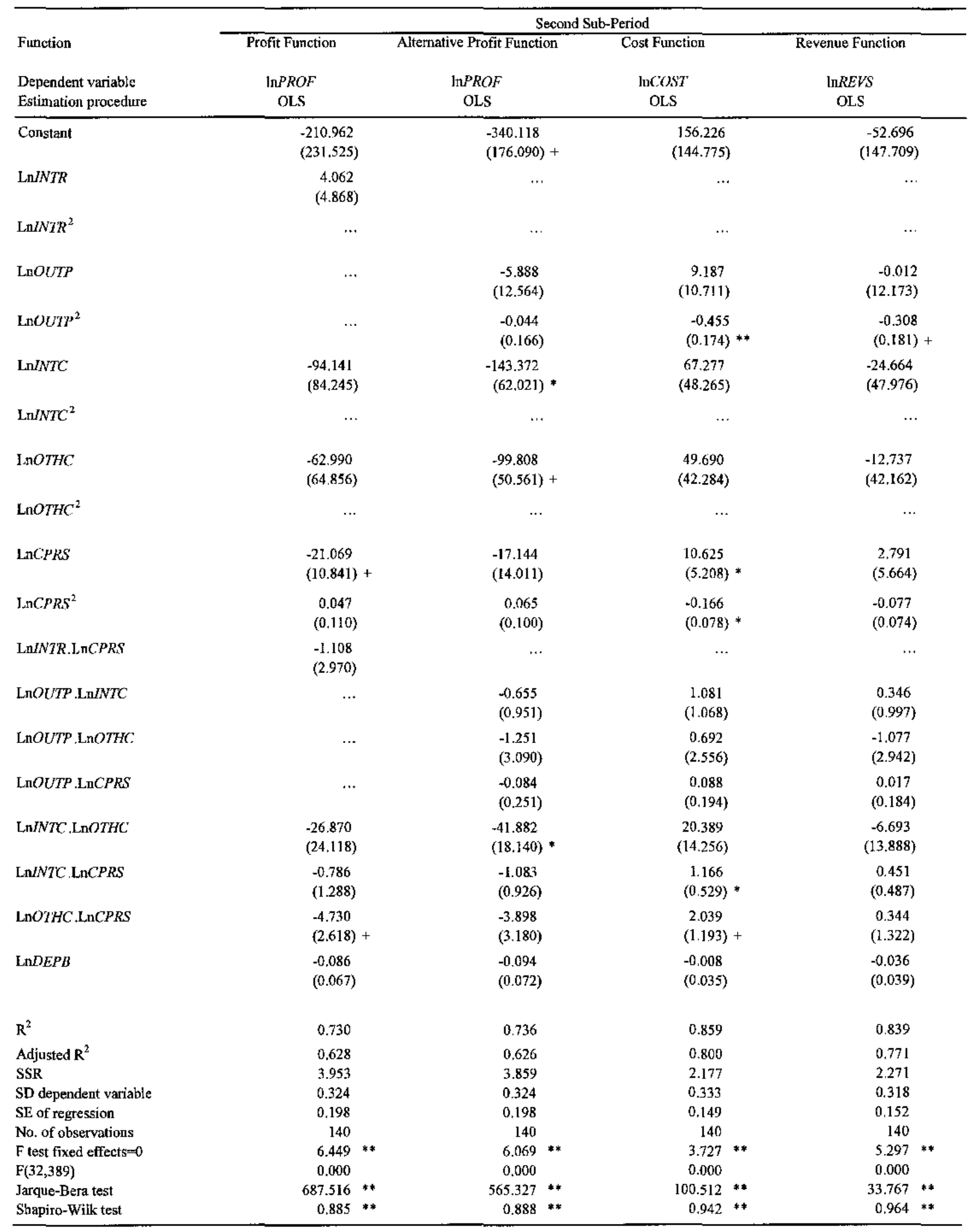

Standard errors in parentheses. Standard errors are heteroskedasticity consistent. ${ }^{* *}$ denotes significance at at least the 1 percent level;

* denotes significance at at least at the 5 percent level; + denotes significance at at least the 10 percent level. 
Table 2 (Continued). Estimated Coefficients of Efficiency Frontiers

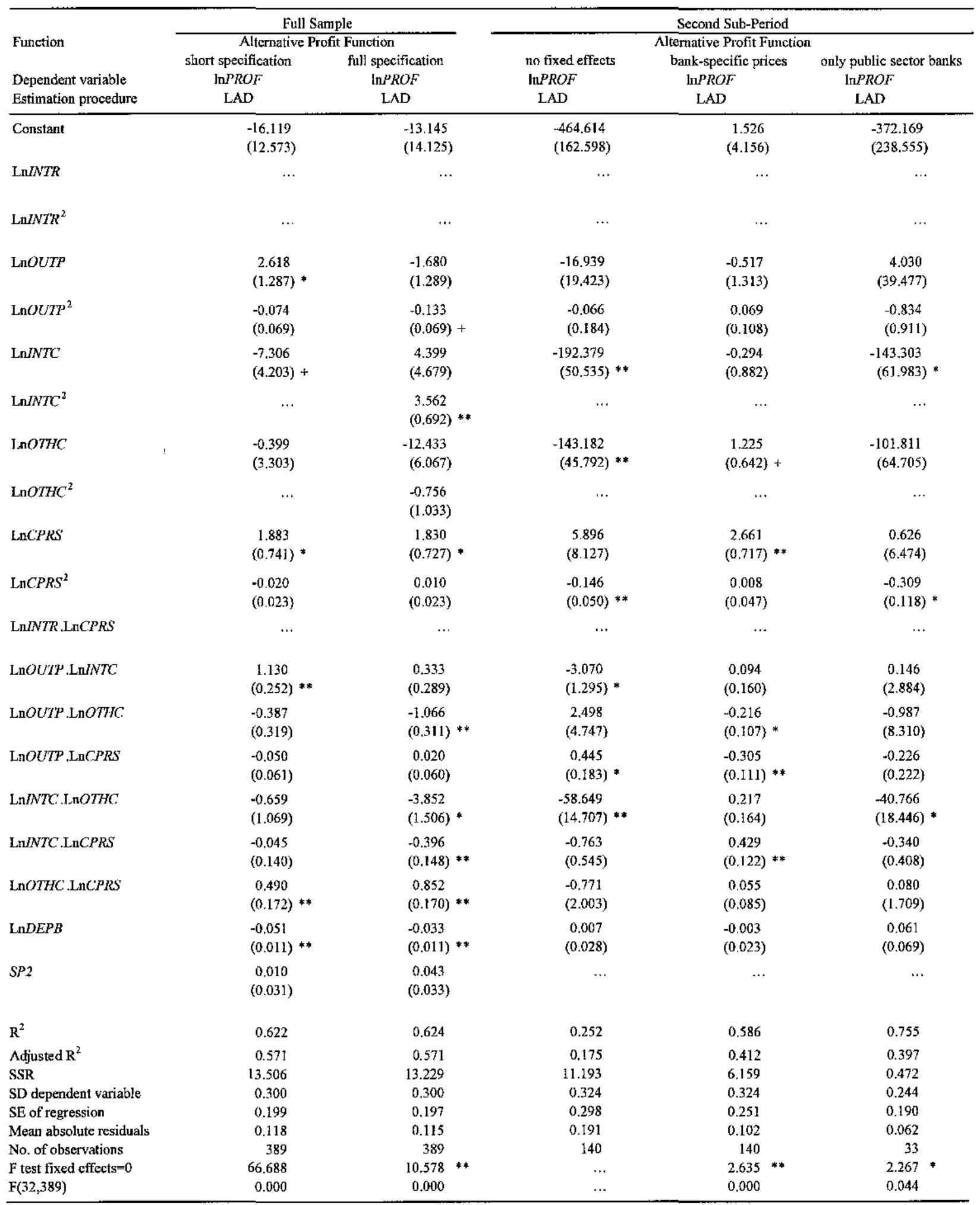

Standard errors in parentheses. ** denotes significance at at least the 1 percent level; * denotes significance at at least at the 5 percent level;

+ denotes significance at at least the 10 percent level. 
When the fixed effects for the individual banks are excluded, the remaining estimated coefficients tend to be larger in absolute terms and more significant; the $\mathrm{R}^{2}$ statistic is cut by more than half. In contrast, when the alternative profit function is estimated using bankspecific prices, that is, unit costs based on the ration of costs to payable liabilities for each bank individually, many of the estimated coefficients are smaller in absolute magnitude and less significant, while the overall $\mathrm{R}^{2}$ statistic is reduced modestly. Including only public sector banks in the sample does not yield qualitative very different estimated coefficients, except that the fixed effects are jointly much less significant, suggesting that this group of banks are relatively homogeneous (although some individual coefficient estimates are significant).

\section{B. Estimation of Relative Efficiency}

It is now possible to estimate the average deviation from best practice-that is to say, Xinefficiency - in terms of profitability, cost efficiency, and revenue efficiency, as explained above (see equation (2)). In particular, the average difference between the estimated coefficients on the fixed effects and the highest coefficient (lowest for the cost function) can be calculated for various categories of banks, using the coefficients and efficiency frontier estimated for the relevant period. The results are shown in Table 3.

The deviations are substantial, but vary over time and across banks. For all banks, differences in relative X-inefficiency are sizeable and persistent, and are seen on both the revenue and the cost side. The divergence in profitability was indeed somewhat larger in the second, postreform sub-period (based on either the profit function or the alternative profit function), due to greater relative inefficiency in generating revenue; relative cost inefficiency declined between the first and second sub-periods, so that average cost $\mathrm{X}$-inefficiency became less pronounced than revenue $\mathrm{X}$-inefficiency.

The profitability of the public sector banks was always depressed by relative X-inefficiency greater than that of banks in general, even allowing for differences in the level of output, capitalization, and dependence on deposits. Their relative unprofitability can be traced to both cost and revenue inefficiency. Over time their relative profit efficiency increased because their cost efficiency improved substantially; their revenue efficiency deteriorated, but not as much as for banks as a whole. The standard errors of the public sector banks' Xinefficiency measures were much higher in the second period, suggesting that some of these banks were more successful than others in adapting to the new circumstances. 
Table 3. Estimated Average Profitability, Cost, and Revenue X-inefficiency (Standard errors in parentheses)

\begin{tabular}{lll}
\hline Profit Function & Alternative \\
Profit Function & Cost Function & $\begin{array}{l}\text { Revenue } \\
\text { Function }\end{array}$ \\
\hline
\end{tabular}

\section{LAD estimates}

First sub-period

All banks

Public sector banks

Second sub-period

All banks

Public sector banks
0.412

(0.225)

0.560
$(0.294)$

0.170
$(0.059)$

0.197

$(0.138)$
0.600

(0.303)

0.170

(0.062)
0.413

(0.225)

0.180

$(0.142)$

OLS estimates
0.485

0.736

$(0.081)$

$(0.108)$

0.641

(0.038)

0.394

0.681

(0.131)

(0.120)

0.608

$(0.081)$

(0.106)

First sub-period

All banks

$$
\begin{gathered}
0.544 \\
(0.289)
\end{gathered}
$$

0.548

0.684

0.775

(0.295)

(0.115)

(0.112)

Public sector banks

$$
\begin{gathered}
0.172 \\
(0.062)
\end{gathered}
$$

0.154

0.534

0.705

(0.052)

(0.046)

(0.048)

Second sub-period

All banks

$$
\begin{gathered}
0.359 \\
(0.222)
\end{gathered}
$$

0.351

0.704

0.711

(0.215)

(0.129)

(0.122)

Public sector banks

$$
\begin{gathered}
0.138 \\
(0.111)
\end{gathered}
$$

0.129

0.559

0.701

(0.104)

(0.099)

(0.112) 
The results for LAD and OLS estimates are generally similar, except the OLS measures of profitability and revenue X-inefficiency tend to be lower in absolute terms, and those of cost efficiency higher than the LAD measures. The standard error of the OLS measures is also greater. According to the OLS estimates, the public sector banks' revenue X-inefficiency worsened only marginally between the first and second sub-periods while their cost efficiency improved, yet their profitability X-inefficiency deteriorated noticeably; changes in the LAD measures are more internally consistent.

These results suggest that the financial sector reforms, and in particular the entry of new, private banks did not lead to an overall convergence in performance. The new banks could adopt the most up-to-date practices and specialize in the most profitable market segments, whereas existing banks and in particular the public sector banks may have been burdened by outdated practices and commitments to less profitable activities. However, there was marked "catching up" in terms of cost efficiency. It seems on balance that deregulation increased the penalty for being inefficient.

More insight into some of these relationships can be obtained by testing for differences between the average relative efficiency of various categories of bank. The bank-specific dummy variables that capture fixed effects are replaced by dummies that identify categories of banks. Specifically, dummies were included for public-sector banks (including those eventually privatized), the banks that were privatized, and the private domestic banks, plus a dummy for each of these categories in the second sub-period; the coefficients on all other variables were allowed to vary freely across sub-periods. ${ }^{22}$ The significance of the estimated coefficients on the dummy variables can be tested by conventional t-statistics.

${ }^{21}$ To clarify the approach, let the dependent variable be $y$, the vector of non-dummy explanatory variables be $x, d$ be the set of three dummy variables for the bank categories, and $S P 2$ is the dummy variable that identifies the second sub-period. Then the specification is:

$$
y=\beta_{1}{ }^{\prime} x+\beta_{2}{ }^{\prime} x \cdot S P 2+\beta_{3}{ }^{\prime} d+\beta_{4}{ }^{\prime} d . S P 2+\text { error terms, }
$$

which is estimated using the full sample. Results were similar when the tests were performed, mutatis mutandis, on the sub-periods individually.

${ }^{22}$ The foreign banks implicitly constitute the "benchmark." For testing purposes the public sector bank category includes throughout the sample period the banks that were privatized. Hence, the coefficient on the privatized banks dummy measures the extent to which those banks differed from the non-privatized public sector banks. There were no private, domestic banks in the first sub-period. 
The results in Table 4 confirm that the public sector banks tended to suffer both cost and revenue inefficiencies, although they improved relative to other banks in the post-reform subperiod. The banks that were eventually privatized seem to have been relatively efficient in terms of revenue performance even before reform, and increased their lead over the banks that remained in the public sector after they were privatized, but their cost efficiency was somewhat worse. Possibly, both the preparation for privatization, and the new incentives and scope for profit maximization thereafter induced them to seek higher revenues, but they could do little about their cost structure. The private domestic banks and the foreign banks seem to have been about equally profitable. The private banks tended to have lower revenues and especially lower costs, which may reflect differences in specialization. The LAD and OLS results are similar.

\section{Effect of Structural Factors and Market Conditions}

The test results presented above provide an indication of the gains and losses in relative efficiency achieved by various groups of banks across time. The evolution of overall performance will depend not only on such gains and losses, but also on changes in structural features of the banking system, such as technological developments, the opening of new markets, and the degree of competitiveness of the sector, and on changes in market conditions, such as interest rates. It is therefore valuable to decompose changes in average profitability, costs, and revenue into the part attributable to these factors, as explained above (see equation (3)). For each variable, the average (log) level in the first and second subperiods is calculated, and the average in the second period is projected based on the equation estimate from the first sub-period and the values of the explanatory variables from the second sub-period.

Table 5 contains the estimates of the separate effects of structural factors and market conditions on the variables of interest, for all banks and for the public sector banks alone (including the privatized banks). For all banks, average profitability improved only modestly between the first and second sub-periods, but the improvement for the public sector banks was slightly greater. Changes in structural features tended to raise profitability, whereas changes in market conditions lowered it, but when looking at public sector banks alone the evidence is mixed. 
Table 4. Tests of Significance of Sectoral Dummy Variables

\begin{tabular}{|c|c|c|c|c|}
\hline & Profit Function & $\begin{array}{c}\text { Alternative } \\
\text { Profit Function }\end{array}$ & Cost Function & $\begin{array}{l}\text { Revenue } \\
\text { Function }\end{array}$ \\
\hline & \multicolumn{4}{|c|}{ LAD estimates } \\
\hline Public banks & 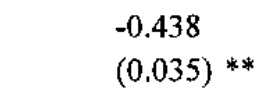 & $\begin{array}{l}-0.530 \\
(0.037) * *\end{array}$ & $\begin{array}{c}0.198 \\
(0.032) * *\end{array}$ & $\begin{array}{l}-0.305 \\
(0.035) * *\end{array}$ \\
\hline Public banks in last sub-period & $\begin{array}{c}0.171 \\
(0.057) *\end{array}$ & $\begin{array}{c}0.137 \\
(0.056) *\end{array}$ & $\begin{array}{l}-0.043 \\
(0.049)\end{array}$ & $\begin{array}{c}0.163 \\
(0.054) * *\end{array}$ \\
\hline Privatized banks & $\begin{array}{c}0.057 \\
(0.042)\end{array}$ & $\begin{array}{c}0.046 \\
(0.040)\end{array}$ & $\begin{array}{c}0.055 \\
(0.035)\end{array}$ & $\begin{array}{c}0.111 \\
(0.038) * *\end{array}$ \\
\hline Privatized banks in last sub-period & $\begin{array}{c}0.255 \\
(0.099) *\end{array}$ & $\begin{array}{c}0.311 \\
(0.090) * *\end{array}$ & $\begin{array}{c}0.282 \\
(0.080) * *\end{array}$ & $\begin{array}{c}0.341 \\
(0.087)^{* *}\end{array}$ \\
\hline \multirow[t]{2}{*}{ Private banks } & $\begin{array}{l}-0.007 \\
(0.041)\end{array}$ & $\begin{array}{c}0.019 \\
(0.038)\end{array}$ & $\begin{array}{l}-0.227 \\
(0.033) * *\end{array}$ & $\begin{array}{l}-0.114 \\
(0.036)^{* *}\end{array}$ \\
\hline & \multicolumn{4}{|c|}{ OLS estimates } \\
\hline Public banks & $\begin{array}{l}-0.436 \\
(0.042) * *\end{array}$ & $\begin{array}{l}-0.544 \\
(0.052) * *\end{array}$ & $\begin{array}{c}0.215 \\
(0.046) * *\end{array}$ & $\begin{array}{l}-0.232 \\
(0.061)^{* *}\end{array}$ \\
\hline Public banks in last sub-period & $\begin{array}{c}0.109 \\
(0.083)\end{array}$ & $\begin{array}{c}0.185 \\
(0.094) *\end{array}$ & $\begin{array}{l}-0.111 \\
(0.066)+\end{array}$ & $\begin{array}{c}0.106 \\
(0.084)\end{array}$ \\
\hline Privatized banks & $\begin{array}{c}0.077 \\
(0.030)^{*}\end{array}$ & $\begin{array}{c}0.048 \\
(0.028)+\end{array}$ & $\begin{array}{c}0.072 \\
(0.033) *\end{array}$ & $\begin{array}{c}0.090 \\
(0.034) * *\end{array}$ \\
\hline Privatized banks in last sub-period & $\begin{array}{c}0.266 \\
(0.166)\end{array}$ & $\begin{array}{c}0.253 \\
(0.165)\end{array}$ & $\begin{array}{c}0.300 \\
(0.069) * *\end{array}$ & $\begin{array}{l}0.360 \\
(0.098) * *\end{array}$ \\
\hline Private banks & $\begin{array}{c}0.041 \\
(0.064)\end{array}$ & $\begin{array}{c}0.039 \\
(0.061)\end{array}$ & $\begin{array}{l}-0.181 \\
(0.048) * *\end{array}$ & $\begin{array}{l}-0.121 \\
(0.051) *\end{array}$ \\
\hline
\end{tabular}

Standard errors in parentheses. $* *$ denotes significance at at least the 1 percent level;

* denotes significance at at least at the 5 percent level; + denotes significance at at least the 10 percent level.

Estimated over full sample, allowing all other parameters to change between sub-periods.

OLS standard errors are heteroskedasticity-consistent. 
Table 5. Decomposition of Changes in Profitability, Costs, and Revenue 1/

\begin{tabular}{lcccc}
\hline & Profit & Alternative & Cost & Revenue \\
Function & Profit & Function & Function \\
& & Function & & \\
\hline
\end{tabular}

LAD estimates

All banks

Total change

Attributable to technology and market structure

Attributable to market conditions

Public sector banks

Total change

Attributable to technology and market structure

Attributable to market conditions
1.128

1.343

0.840

1.563

0.863

1.811

1.131

0.852

1.327

Attributable to market conditions

Public sector banks

Total change

Attributable to technology and market structure

Attributable to market conditions

$\begin{array}{llll}1.131 & 1.130 & 1.383 & 1.312 \\ 0.852 & 1.062 & 1.168 & 1.172 \\ 1.327 & 1.064 & 1.184 & 1.120 \\ & & & \\ 1.426 & 1.437 & 1.189 & 1.218 \\ 0.928 & 1.709 & 1.273 & 1.326 \\ 1.538 & 0.841 & 0.934 & 0.918\end{array}$

$\begin{array}{lll}1.589 & 1.211 & 1.219 \\ 1.669 & 1.432 & 1.485 \\ 0.952 & 0.846 & 0.821\end{array}$

.

1.129

1.134

OLS estimates

1.130

120

$\begin{array}{ll}1.240 & 1.134\end{array}$

219

0.821

1/ Change in average values of variables between 1981-1992 and 1993-97. 
Profitability did not increase very substantially because both costs and revenues increased. Changes in market conditions contributed to the rise in average costs, but in addition the financial sector reform was associated with a structural rise in bank costs, even holding market conditions constant. On the revenue side, market conditions and structural factors contributed about equally to higher average receipts for the banking sector as a whole. This result, which parallels that obtained by Grabowski, Rangan and Rezvanian (1994) and Berger and Mester (1997, 2001) for U.S. banks, and Lozano-Vivas (1998) for Spanish banks, may be because banks had to offer better services in the more competitive post-reform environment, and new market segments opened up where both unit costs and unit revenues were higher; higher costs need not be interpreted as a technological regression or a slackening of market discipline. ${ }^{23}$ The public sector banks seem to have made good progress in adding to revenue through structural changes, while market conditions turned increasingly unfavorable to them.

OLS and LAD results are again mostly similar. However, the OLS results for the standard profit function suggest that changes in technological and market structure were harmful to efficiency despite an improvement in revenue efficiency; those of the alternative profit function show an improvement in profit efficiency due to changes in market conditions, despite a rise in cost greater than than the rise in revenue.

\section{Conclusions}

Financial market deregulation and liberalization has transformed the banking systems of a large number of countries over the last two decades. The reforms are sure to have a profound effect on the development of the financial system in these countries, and their overall macroeconomic performance. The transformation has been perhaps most profound in some developing countries, where previously a dirigiste approach to the financial sector prevailed and where there was very little scope for competition, the allocation of resources according to commercial criteria, or the introduction of new products and services. Pakistan was one such country which, between 1988 and 1992, very substanitally de-regulated interest rates and the allocation of credit, liberalized entry into the sector and privatized major state-owned banks, and introduced modern prudential regulation and supervision.

The effects of the financial sector reform on the profitability and efficiency of the Pakistani banking system is the subject of this paper. To assess these effects, profitability, cost, and revenue efficiency frontiers are estimated, from which can be derived certain measures of the efficiency of the banking system (or of sections of the banking system) relative to the best available practice. Furthermore, one can decompose changes in measures of performance

${ }^{23}$ This tendency seems to be widespread in banking. Berger and Mester (2001) find that American banks "appeared to provide additional or higher quality services that raised costs but also raised revenues by more than the cost increases" during 1991-97, a period of relatively limited deregulation. 
into that component attributable to market conditions, such as interest rates, and that attributable to structural factors, such as production technology and competitive behavior.

Perhaps the main result obtained was that that principal effect of financial market reform seems to have been the increase in both revenues and costs, which suggests that much of the benefit of reform was passed to the consumers of bank output (such as borrowers and those needing transaction services, who received more and better "products") and those supplying banks with inputs (such as depositors). The reform program did not lead to a rise in overall profitability, which was held down by a combination of rising deposit interest rates and intensified competition. Nor did it lead to a strong convergence in all aspects of efficiency, because, it seems, in the liberalized environment strong banks were generally able to keep ahead of those trying to catch up. The public sector banks and the privatized banks made progress in improving cost efficiency, and their relative profitability improved noticeably, if from a low base. The reforms did allow all banks, including the public sector banks, to improve their underlying revenue performance, and especially the privatized banks seem to have succeeded in expanding their revenue base and in this way regainng profitability. 


\section{REFERENCES}

Bandiera, Oriana, Gerard Caprio, Patrick Honohan, and Fabio Schiantarelli, 2000, "Does Financial Reform Raise or Reduce Saving?," The Review of Economics and Statistics, Vol. 82(2), pp. 239-263.

Bauer, Paul W., Allen N. Berger, Gary D. Ferrier, and David B. Humphrey, 1998, "Consistency Conditions for Regulatory Analysis of Financial Institutions: A Comparison of Frontier Efficiency Methods," Journal of Economics and Business, Vol. 50, pp. 85-114.

Berger, Allen N., D. Hancock, and David B. Humphrey, 1993, "Bank Efficiency Derived from the Profit Function," Journal of Banking and Finance 17, pp. 317-347.

Berger, Allen N., David B. Humphrey, and Lawrence B. Pulley, 1996, "Do Consumers Pay for One-Stop Banking? Evidence from an alternative revenue function," Journal of Banking and Finance 20, pp. 1601-21.

Berger, Allen N., and David B. Humphrey, 1997, "Efficiency of Financial Institutions: International Survey and Directions for Future Research," European Journal of Operational Research 98(2), pp. 175-212.

Berger, Allen N., and Loretta J. Mester, 1997, "Efficiency and Productivity Change in the U.S. Commercial Banking Industry: A Comparison of the 1980s and 1990s," Federal Reserve Bank of Philadelphia Working Paper 97-5, May, Philadelphia.

Berger, Allen N., and Loretta J. Mester, 2001, "Explaining the Dramatic Changes in Performance of U.S. Banks: Technological Change, Deregulation, and Dynamic Changes in Competition," Federal Reserve Bank of Philadelphia Working Paper 01-6, April, Philadelphia.

Cornwell, Christopher, Peter Schmidt, and Robin C. Sickles, 1990, "Production Frontiers with Cross-Sectional and Time-Series Variation in Efficiency Levels," Journal of Econometrics, Vol. 46, pp. 185-200.

Demetriades, Panicos, and Kul B. Luintel, 1996, "Financial Development, Economic Growth and Banking Sector Controls: Evidence from India," The Economic Journal, Vol. 106, pp. 359-374.

Fanelli, Jose M., and Rohinton Medhora, 1998, Financial Reform in Developing Countries, (London, MacMillan Press).

Gelb, Alan H., 1989, "Financial Policies, Growth, and Efficiency," Policy, Planning and Research Working Paper WPS 202 (Washington: The World Bank). 
Gibert, R. Alton, and Paul W. Wilson, 1998, "Effects of Deregulation on the Productivity of Korean Banks," Journal of Economics and Business, Vol. 50, pp. 133-155.

Grabowski. Richard, Nanda Rangan, and Rasoul Rezvanian, 1994, "The Effects of Deregulation on the Efficiency of U.S. Banking Firms," Journal of Business and Economics, Vol. 46, pp. 39-54.

Hardy, Daniel C., 2000, "Bidding Behavior in Treasury Bill Auctions: Evidence from Pakistan," IMF Working Paper 00/111, (Washington: International Monetary Fund).

Humphrey, David B., and Lawrence B. Pulley, 1997, "Banks' Responses to Deregulation: Profits, Technology, and Efficiency," Journal of Money, Credit and Banking, Vol. 29, pp. 71-93.

Jbili, Abdelali, Klaus Enders, and Volker Treichel, 1997, "Financial Sector Reforms in Algeria, Morocco, and Tunisia: A Preliminary Assessment," IMF Working Paper 97/81, (Washington: International Monetary Fund).

Johnston, R. Barry, and Ceyla Pazarbaşioglu, 1995, "Linkages Between Financial Variables, Financial Sector Reform and Economic Growth and Efficiency," IMF Working Paper 95/103, (Washington: International Monetary Fund).

Khan, Ashfaque H., and Lubna Hasan, 1998, "Financial Liberalization, Savings and Economic Development in Pakistan," Economic Development and Cultural Change, Vol. 46, pp. 581-598.

Khan, Shahrukh Rafi, and Safiya Aftab, 1994, "Assessing the Impact of Financial Reforms on Pakistan's Economy," Pakistan Journal of Applied Economics, Vol. X No. $1 \& 2$, pp. 99-116.

Leightner, Jonathen E., and C. A. Knox Lovell, 1998, "The Impact of Financial Liberalization on the Performance of Thai Banks," Journal of Economics and Business, Vol. 50, pp. 115-31.

Lozano-Vivas, Ana, 1998, "Efficiency and Technical Change for Spanish Banks," Applied Financial Economics, Vol. 8, pp. 289-300.

Schmidt, Peter, and Robin C. Sickles, 1990, "Production Frontiers and Panel Data," Journal of Business and Economic Statistics, Vol. 2, pp. 367-374.

Swary, Itzhak, and Barry Topf, 1992, Global Financial Deregulation; Commercial Banking at the Crossroads, (Cambridge MA: Blackwell). 
Ul Haque, Nadeem, and Shadid Kardar, 1995, "Development of the Financial Sector in Pakistan," in Shahid N. Zahid (ed.), 1995, Financial Sector Development in Asia: Country Studies, Asian Development Bank, Manila.

U1 Haque, Nadeem, 1997, "Financial Market Reform in Pakistan," The Pakistan Development Review, 36:4 Part II, pp. 839-854.

Zahid, Shahid N. (ed.), 1995, Financial Sector Development in Asia: Country Studies, Asian Development Bank, Manila. 